\title{
KORELASI LINGKAR SKROTUM DENGAN BOBOT BADAN, VOLUME SEMEN, KUALITAS SEMEN, DAN KADAR TESTOSTERON PADA KAMBING KEJOBONG MUDA DAN DEWASA
}

\section{THE CORRELATIONS OF SCROTAL CIRCUMFERENCE AND BODY WEIGHT, SEMEN VOLUME, SEMEN QUALITY AND TESTOSTERONE LEVELS OF YOUNG AND ADULT KEJOBONG BUCKS}

\author{
Ono Syamyono*, Daud Samsudewa, dan Enny Tantini Setiatin \\ Fakultas Peternakan dan Pertanian, Universitas Diponegoro, Kompleks drh. R. Soejono Koesoemowardojo, Tembalang, \\ Semarang, 50275
}

\section{INTISARI}

Penelitian ini bertujuan untuk mengetahui korelasi lingkar skrotum dengan bobot badan, volume semen, kualitas semen, dan kadar testosteron pada kambing Kejobong muda dan dewasa. Penelitian ini dilaksanakan pada bulan Maret-Mei 2013 di Purbalingga, Semarang, dan Yogyakarta. Materi yang digunakan adalah 35 ekor kambing Kejobong jantan, terbagi atas 2 kelompok umur, yaitu muda 20 ekor (8-12 bulan) dan dewasa 15 ekor (13-24 bulan). Variabelvariabel yang diamati meliputi korelasi antar lingkar skrotum dengan bobot badan, volume semen, abnormalitas, konsentrasi, morfologi, spermatozoa hidup, dan kadar testosteron. Kadar testosteron dianalisis menggunakan metode Enzyme-linked Immunosorbent Assay (ELISA). Hasil penelitian menunjukkan bahwa terdapat korelasi positif antara lingkar skrotum dengan bobot badan pada kambing Kejobong muda sebesar $r=0,60(\mathrm{P}<0,05)$ dengan persamaan regresi $\mathrm{Y}=-50,856+3,666 \mathrm{X}$, namun tidak ada korelasi pada kambing Kejobong dewasa. Lingkar skrotum tidak berkorelasi dengan volume, motilitas, konsentrasi, morfologi, dan spermatozoa hidup pada kambing Kejobong muda dan dewasa. Lingkar skrotum berkorelasi negatif dengan kadar testosteron pada kambing Kejobong muda sebesar $\mathrm{r}=-0,66(\mathrm{P}<0,05)$ dengan persamaan regresi $\mathrm{Y}=14,353-0,436 \mathrm{X}$, namun tidak ada korelasi pada kambing Kejobong dewasa. Hasil penelitian ini dapat disimpulkan bahwa lingkar skrotum berkorelasi positif dengan bobot badan dan berkorelasi negatif dengan kadar testosteron pada kambing Kejobong muda. Lingkar skrotum tidak berkorelasi dengan volume dan kualitas semen baik pada kambing Kejobong muda maupun dewasa.

(Kata kunci: Lingkar skrotum, Bobot badan, Kualitas semen, Kadar testosteron, Kambing Kejobong)

\section{ABSTRACT}

This research was aimed to determine the correlation between scrotal circumference and body weight, semen volume, semen quality and testosterone level of young and adult Kejobong bucks. This study was conducted in March-May 2013 in Purbalingga, Semarang and Yogyakarta. Materials used were 35 of Kejobong bucks, consisted of 20 heads of young (aged 8-12 months) and 15 heads of adult (aged 13-24 months) bucks. Variables observed were correlation between scrotal circumference and body weight, semen volume, sperm motility, concentration, abnormality, life spermatozoa and testosterone level. Testosterone level were measured using the Enzyme-linked Immunosorbent Assay (ELISA) method. Results showed there was positive correlation between scrotal circumference and body weight in young Kejobong $r=0.60(P<0.05)$ with equation $Y=-50.856+3.666 X$, but there was no correlation in adult bucks. Scrotal circumference were not correlated with the volume, motility, concentration, abnormality and live sperm in young and adult Kejobong bucks. Scrotal circumference had negative correlation with testosterone levels in young Kejobong bucks $r=-0.66(P<0.05)$ with equation $Y=14.353-0.436 X$, but there was no correlation in adult ones. It might be concluded that scrotal circumference had positive correlation with body weight and negative correlation with testosterone level of young Kejobong bucks. However, scrotal circumference had no correlation with the volume and semen quality of young and adult Kejobong bucks.

(Key words: Scrotal circumference, Body weight, Semen quality, Testosterone level, Kejobong bucks)

\section{Pendahuluan}

Kambing Kejobong merupakan salah satu sumber daya genetik Jawa Tengah, tepatnya di kabupaten Purbalingga. Berdasarkan karakteristik kualitatif dan kuantitatifnya kambing Kejobong merupakan hasil persilangan antara kambing

\footnotetext{
* Korespondensi (corresponding author):

Telp. +62 81320690042

E-mail: onosyam@gmail.com
}

lokal (kambing Kacang) dengan kambing Peranakan Ettawa (PE), sedangkan berdasarkan ukuran-ukuran morfologi tubuh bagian luar menunjukkan bahwa ukuran tubuh kambing Kejobong di antara kambing PE dan kambing Kacang (Sodiq, 2009). Ukuran tubuh kambing Kejobong dengan umur yang sama lebih besar dari kambing Kacang tetapi lebih kecil dari kambing PE. 
Pramono et al. (2005) menyatakan bahwa kambing Kejobong memiliki beberapa keunggulan yaitu sebagai berikut: 1) Warna spesifik yang seragam yaitu hitam, sehingga sering disebut kambing Hitam Kejobong; 2) Mempunyai potensi jarak beranak (calving interval) yang pendek; 3) Mempunyai sifat beranak kembar dalam satu kelahiran (prolifik). Sodiq (2009) menjelaskan bahwa kambing Kejobong yang memiliki proporsi warna tubuh dominan hitam ada $74,45 \%$, sedangkan yang memiliki warna hitam polos pada seluruh tubuhnya ada $56,49 \%$.

Pelestarian dan pengembangan kambing Kejobong bisa dilakukan dengan meningkatkan kualitas bibit yang dihasilkan melalui perkawinan dengan jantan unggul. Pejantan memiliki peranan yang sangat strategis dalam menghasilkan keturunan dan meningkatkan performa generasi berikutnya. Penilaian keunggulan seekor pejantan dapat diduga berdasarkan ukuran testisnya. Besar testis diukur dengan cara mengukur lingkar skrotum. Lingkar skrotum dapat digunakan sebagai salah satu parameter untuk seleksi pejantan. Lingkar skrotum berhubungan dengan potensi produksi spermatozoa dan testosteron. Kostaman et al. (2004) menyatakan bahwa ukuran testis berhubungan secara positif terhadap kualitas semen, kemampuan pejantan untuk mengawini sejumlah betina dan tingginya fertilitas.

Kemampuan pejantan mengawini betina berhubungan dengan libido yang dimiliki pejantan tersebut yang dipengaruhi oleh kadar testosteron (Wahid dan Yunus, 1995). Testosteron juga berperan dalam pematangan spermatozoa dalam epididimis, pertumbuhan organ kelamin, dan sifatsifat kelamin sekunder (Toelihere, 1993); peningkatan kekuatan dan massa otot, penguatan dan pertumbuhan tulang (Pineda dan Dooley, 2003). Soeparno (2005) menyatakan bahwa sekresi testosteron yang tinggi menyebabkan sekresi androgen ikut naik, sehingga hormon ini menyebabkan pertumbuhan yang lebih cepat pada ternak jantan terutama setelah munculnya sifat kelamin sekunder.

Mengingat peranan testis yang sangat penting dan untuk mengetahui pejantan kambing Kejobong unggul berdasarkan ukuran lingkar skrotum (LS) maka informasi mengenai korelasi LS dengan bobot badan, volume semen, kualitas semen, dan kadar testosteron pada kambing Kejobong penting untuk diketahui. Oleh karena itu penelitian ini bertujuan untuk mengetahui korelasi tersebut. Hasil penelitian ini diharapkan dapat memberikan informasi kepada masyarakat dalam menduga pejantan kambing Kejobong unggul berdasarkan ukuran LS.

\section{Materi dan Metode}

Penelitian ini dilaksanakan pada bulan Maret sampai Mei 2013, di Purbalingga, Semarang, dan Yogyakarta. Analisis semen secara makroskopis dan mikroskopis dilakukan di Purbalingga. Analisis morfologi semen dilakukan di Laboratorium Genetika, Pemuliaan dan Reproduksi, Fakultas Peternakan dan Pertanian, Universitas Diponegoro, Semarang. Analisis kadar testosteron dilakukan di Laboratorium Fisiologi, Fakultas Kedokteran Hewan, Universitas Gadjah Mada, Yogyakarta.

Materi yang digunakan adalah 35 ekor kambing Kejobong jantan yang terbagi atas 2 kelompok umur, yaitu muda 20 ekor (8-12 bulan) dan dewasa 15 ekor (13-24 bulan). Semua ternak penelitian dipelihara di Kelompok Tani Ternak yang ada di kecamatan Kejobong, Pengadegan, dan Bukateja kabupaten Purbalingga. Penelitian ini menggunakan metode survei dan teknik penentuan sampel menggunakan metode purposive sampling. Penentuan umur kambing dengan melihat pergantian gigi seri.

Penimbangan bobot badan dilakukan satu kali pada pagi hari sebelum ternak diberi pakan. Penimbangan menggunakan timbangan badan kapasitas $50 \mathrm{~kg}$ dengan tingkat ketelitian $0,1 \mathrm{~kg}$. Pengukuran LS dilakukan dua ulangan dengan mengukur bagian terlebar dari skrotum pada posisi ternak berdiri normal dengan menggunakan pita ukur. Penampungan semen dilakukan dua tahap. Tahap pertama dilakukan untuk memastikan pejantan mengeluarkan semen, tahap kedua dilakukan tiga sampai empat hari setelah penampungan tahap pertama. Semen pada penampungan tahap kedua yang diamati secara makroskopis dan mikroskopis. Penampungan semen dilakukan dengan menggunakan vagina buatan.

Pengukuran kadar testosteron dilakukan terhadap plasma darah dari pejantan yang ditampung semennya. Pengambilan sampel darah dilakukan satu kali pada pagi hari sesaat setelah ternak ditampung semennya pada tahap kedua. Sampel darah yang diambil sebanyak 5-10 ml menggunakan spuit kemudian dimasukkan ke dalam tabung Ethylenediaminetetraacetic acid (EDTA) selanjutnya disentrifugasi dengan kecepatan 3500 rpm selama 10 menit. Plasma darah yang diperoleh dipindahkan ke dalam effendorf kemudian disimpan di dalam freezer. Analisis kadar testosteron menggunakan metode Enzyme-linked Immunosorbent Assay (ELISA).

Data yang diperoleh dianalisis secara deskriptif dalam bentuk persentase, nilai rerata \pm standar deviasi, dan analisis hubungan dengan uji korelasi Pearsons dan regresi (Steel dan Torrie, 
1993). Pengolahan data menggunakan bantuan program SPSS versi 20.0.

\section{Hasil dan Pembahasan}

\section{Korelasi lingkar skrotum dengan bobot badan}

Lingkar skrotum dapat digunakan sebagai salah satu parameter untuk seleksi pejantan. Lingkar skrotum mempunyai hubungan yang positif dengan bobot badan (BB) dan erat hubungannya dengan potensi produksi semen seekor pejantan. Hasil analisis dengan uji t menunjukkan bahwa BB dan LS antara kambing Kejobong muda dan dewasa berbeda nyata $(\mathrm{P}<0,05)$. Rerata $\mathrm{BB}$ dan ukuran LS kambing Kejobong muda dan dewasa disajikan pada Tabel 1.

Perbedaan ini dapat dijelaskan karena adanya pengaruh perbedaan umur. Kambing Kejobong muda berumur 8-12 bulan, sedangkan kambing kejobong dewasa berumur 13-24 bulan. Pada umur tersebut kambing Kejobong muda masuk masa akhir pertumbuhan tulang, sedangkan pertumbuhan otot yang melekat ditulang dan deposisi lemak tubuhnya masih lambat, sehingga bobot badannya masih rendah. Kambing Kejobong dewasa pada umur tersebut, pertumbuhan otot yang melekat ditulang sudah mencapai $80-90 \%$ dan deposisi lemak tubuhnya terjadi secara cepat, sehingga bobot badannya lebih berat. Judge et al. (1989) menyatakan bahwa saat kecepatan pertumbuhan mendekati konstan, kemiringan kurva pertumbuhan hampir tidak berubah, dalam hal ini pertumbuhan otot, tulang dan organ-organ penting mulai berhenti, sedangkan penggemukan (fattening) mulai dipercepat. Pertumbuhan tahap lambat terjadi pada saat kedewasaan tubuh telah tercapai.

Perbedaan ukuran LS antara kambing Kejobong muda dan dewasa menunjukkan bahwa testis kambing Kejobong muda masih dalam masa pertumbuhan sejalan dengan pertumbuhan otot dan pertambahan umur. Judge et al. (1989) menyatakan bahwa selama pertumbuhan dan perkembangan serta peningkatan bobot badan terjadi perubahanperubahan komponen tubuh. Berdasarkan konsep pertumbuhan ini, maka setiap kenaikan bobot badan menyebabkan perubahan proporsi organ dan jaringan seperti tulang, otot, dan lemak.

Knight et al. (1984) menyatakan bahwa ukuran testis berkorelasi dengan bobot badan sesuai dengan bertambahnya umur sampai umur tertentu. Pertambahan umur ternak akan mempengaruhi pertambahan ukuran LS. Ukuran LS akan terus bertambah dan mencapai ukuran dan besar yang maksimum pada saat ternak mencapai umur tertentu. Hasil penelitian Samsudewa dan Purbowati (2006) pada domba lokal umur 3, 5, 7, dan 9 bulan menunjukkan bahwa umur mempunyai pengaruh yang sangat nyata terhadap panjang testis dengan persamaan $\mathrm{Y}=3,123+0,193 \mathrm{X}\left(\mathrm{r}^{2}=0,764\right)$ dan umur berpengaruh nyata terhadap lebar testis dengan persamaan $\mathrm{Y}=2,420+0,113 \mathrm{X}\left(\mathrm{r}^{2}=0,414\right)$.

Koyuncu et al. (2005) melaporkan bahwa pada domba Kivircik muda terdapat korelasi sangat nyata antara ukuran testis terhadap umur dan BB. Korelasi antara panjang testis dengan umur sebesar $\mathrm{r}=0,818$, korelasi antara panjang testis dengan BB sebesar $\mathrm{r}=0,923$, dan korelasi antara LS dengan umur sebesar $r=0,722$ sedangkan korelasi antara LS dengan BB sebesar $r=0,845$. Hasil yang sejalan dilaporkan Wahid dan Yunus (1991) pada kambing Kacang, persilangan kambing Anglo Nubian $\mathrm{X}$ Kacang dan persilangan kambing Saanen $X$ Kacang, yang menyatakan bahwa korelasi antara LS dengan BB berturut-turut sebesar 0,90;0,88; dan 0,88 .

Data pada Tabel 2 menunjukkan bahwa ada korelasi antara LS dengan BB pada kambing Kejobong muda, dengan nilai koefisien korelasi $r=0,60$ dan koefisien determinasi $r^{2}=0,36$. Nilai koefisien korelasi $(r=0,60)$ tersebut termasuk sedang, artinya keeratan hubungan antara LS (X) dengan $\mathrm{BB}(\mathrm{Y})$ adalah sedang. Koefisien determinasi $\mathrm{r}^{2}=0,36$, artinya variasi $\mathrm{BB}(\mathrm{Y})$ dapat diterangkan oleh LS (X) sebesar 36\%, menurut persamaan regresi yang diperoleh dari hasil analisis. Variasi BB lainnya sebesar 64\% ditentukan oleh faktor selain LS. Hasil penelitian ini sejalan dengan penelitian Kostaman et al. (2004) pada kambing jantan muda berumur kurang lebih 11 bulan yang melaporkan adanya korelasi sangat kuat dan sangat signifikan antara LS dengan BB, dengan koefisien korelasi $\mathrm{r}=0,99$. Koefisien korelasi, koefisien determinasi dan persamaan regresi antara LS dengan BB kambing kejobong muda dan dewasa disajikan pada Tabel 2.

Korelasi antara LS dengan BB pada kambing Kejobong dewasa menunjukkan tidak ada korelasi $(r=-0,02)$ (Tabel 2). Hal ini dapat dijelaskan bahwa pada kambing Kejobong dewasa umur 13-24 bulan dengan rerata $\mathrm{BB} 37,83 \pm 5,95 \mathrm{~kg}$, pada umur tersebut pertambahan BB ternak lebih banyak dipengaruhi oleh deposisi lemak. Pada umur dewasa tubuh pertumbuhan organ dan tulang sudah optimum, pertumbuhan otot sudah berkurang dan deposisi lemak terjadi secara cepat (Judge et al., 1989). Sumardianto et al. (2013) melaporkan bahwa meat bone ratio kambing Kejobong jantan umur lebih dari 1 tahun (poel 1) adalah 2,87 dengan persentase tulang $26,01 \%$ dari bobot karkas. Semakin besar angka meat bone ratio menunjukkan komposisi daging, lemak dan jaringan ikat pada karkas ternak tersebut semakin besar dibandingkan komposisi tulangnya. 
Tabel 1. Bobot badan dan ukuran lingkar skrotum kambing Kejobong muda dan dewasa (rerata \pm standar deviasi) (body weight and scrotal circumference of young and adult Kejobong bucks (mean \pm standard deviation))

\begin{tabular}{lcc}
\hline \hline \multirow{2}{*}{ Variabel (variable) } & \multicolumn{2}{c}{ Kambing Kejobong jantan (Kejobong buck) } \\
\cline { 2 - 3 } & $\begin{array}{c}\text { Muda (young) } \\
(\mathrm{n}=20)\end{array}$ & $\begin{array}{c}\text { Dewasa }(\text { adult }) \\
(\mathrm{n}=15)\end{array}$ \\
\hline Bobot badan $(\mathrm{kg})($ body weight $(\mathrm{kg}))$ & $32,52 \pm 5,58^{\mathrm{b}}$ & $37,83 \pm 5,95^{\mathrm{a}}$ \\
Lingkar skrotum $(\mathrm{cm})($ scrotal circumference $(\mathrm{cm}))$ & $22,73 \pm 0,93^{\mathrm{b}}$ & $24,06 \pm 1,39^{\mathrm{a}}$
\end{tabular}

$\overline{\mathrm{a}, \mathrm{b}}$ Superskrip berbeda pada baris yang sama menunjukkan berbeda nyata $(\mathrm{P}<0,05)$ (different superscripts at the same row indicate significant differences $(P<0.05))$.

Tabel 2. Koefisien korelasi dan persamaan regresi lingkar skrotum dengan bobot badan kambing Kejobong muda dan dewasa (coefficient of correlation and regression equations of scrotal circumference and body weight of young and adult Kejobong bucks)

\begin{tabular}{lcc}
\hline \hline \multirow{2}{*}{$\begin{array}{c}\text { Korelasi lingkar skrotum dengan bobot badan (correlation } \\
\text { of scrotal circumference with a body weight) }\end{array}$} & $\begin{array}{c}\text { Kumbing Kejobong jantan (Kejobong buck) } \\
(\mathrm{n}=20)\end{array}$ & $\begin{array}{c}\text { Dewasa }(\text { adult }) \\
(\mathrm{n}=15)\end{array}$ \\
\cline { 2 - 3 } Koefisien korelasi (coefficient of correlation) $(\mathrm{r})$ & $0,60 *$ & $-0,02$ \\
Koefisien determinasi (coefficient of determination) $\left(\mathrm{r}^{2}\right)$ & 0,36 & 0,00 \\
Persamaan regresi (regression equations) & $\mathrm{Y}=-50,856+3,666 \mathrm{X}$ & - \\
\hline
\end{tabular}

* Ada korelasi dan berbeda nyata $(\mathrm{P}<0,05)$ (there was a correlation and significant different $(P<0.05))$.

Dengan demikian BB pada kambing Kejobong dewasa tidak berhubungan dengan faktor ukuran LS, tetapi dipengaruhi oleh faktor lain diantaranya adalah kecepatan deposisi lemak. Kecepatan deposisi lemak tiap individu berbeda-beda dipengaruhi oleh faktor genetik, pakan, dan manajemen. Hal ini ditunjukkan dengan tingginya variasi BB pada kambing Kejobong dewasa. Tingginya variasi $\mathrm{BB}$ tersebut pada kambing Kejobong $(\mathrm{CV}=15 \%)$ diantaranya akibat kecepatan deposisi lemak tiap individu yang berbeda-beda.

\section{Volume, kualitas semen, dan kadar testosteron kambing Kejobong muda dan dewasa}

Data pada Tabel 3 menunjukkan bahwa tidak terdapat perbedaan volume semen kambing Kejobong muda dan dewasa. Volume semen hasil penelitian ini lebih rendah jika dibandingkan dengan hasil penelitian Hanum et al. (2012) yang melaporkan bahwa volume semen kambing Kejobong muda dan dewasa berturut-turut yaitu $0,87 \pm 0,14 \mathrm{ml}$ dan $0,60 \pm 0,20 \mathrm{ml}$. Hasil penelitian Kaya et al. (2002) melaporkan bahwa frekuensi ejakulasi berpengaruh terhadap volume semen dan konsentrasi spermatozoa. Rerata volume semen, kualitas semen dan kadar testosteron kambing kejobong muda dan dewasa disajikan pada Tabel 3.

Hasil pengamatan secara makroskopis terhadap warna semen segar kambing Kejobong muda dan dewasa secara umum berwarna krem dengan konsistensi sangat kental (Tabel 3). Hal ini sejalan dengan pendapat Ax et al. (2000) yang menyatakan bahwa semen kambing berwarna putih keabu-abuan sampai krem, dengan volume ejakulasi antara 0,5-1,2 ml. Toelihere (1993) menyatakan bahwa semen segar domba yang berwarna krem dan kental menunjukkan tingginya konsentrasi spermatozoa, sedangkan semen segar yang berwarna seperti air susu dan tingkat kekentalan encer menunjukkan konsentrasi spermatozoa yang rendah.

Rerata $\mathrm{pH}$ semen segar kambing Kejobong muda dan dewasa yaitu $6,41 \pm 0,67$ dan $6,48 \pm 0,17$ (Tabel 3). Nilai $\mathrm{pH}$ semen segar domba yang normal yaitu 5,9-7,3 (Garner dan Hafez, 2000), sedangkan nilai $\mathrm{pH}$ semen segar kambing PE yaitu 6,60 $\pm 0,15$ (Ariantie et al., 2013). Semen dengan pH 6,8 menunjukkan fertilitas yang lebih baik dibandingkan dengan $\mathrm{pH} 7,3$ dan 7,8 (Hastono et al., 2001). Hasil penelitian ini relatif sama dengan penelitian Hanum et al. (2012) yang melaporkan bahwa $\mathrm{pH}$ semen segar kambing Kejobong muda dan dewasa adalah $6,52 \pm 0,16$ dan $6,52 \pm 0,16$. Terjadinya penurunan dan kenaikan $\mathrm{pH}$ disebabkan oleh akumulasi asam laktat hasil metabolisme secara anaerob. Peningkatan $\mathrm{pH}$ juga disebabkan oleh kontaminasi bakteri atau banyaknya spermatozoa yang mati sehingga membentuk amoniak (Toelihere, 1993).

Motilitas spermatozoa pada semen segar kambing Kejobong muda dan dewasa menunjukkan 
motilitas yang tinggi yaitu sebesar $82,00 \pm 8,33 \%$ dan $85,00 \pm 5,40 \%$ (Tabel 3). Hasil ini lebih tinggi dari pendapat Garner dan Hafez (2000) yang menyatakan bahwa motilitas spermatozoa pada semen segar domba mempunyai rerata sekitar 60-80\%. Ax et al. (2000) menyatakan bahwa persentase motilitas spermatozoa normal agar dapat diolah lebih lanjut adalah di atas 70\%. Hasil penelitian ini juga lebih tinggi dari hasil penelitian Hanum et al. (2012) yang melaporkan bahwa motilitas progresif spermatozoa semen segar kambing Kejobong muda dan dewasa berturut-turut sebesar $60,16 \pm 4,26 \%$ dan $56,43 \pm 6,51 \%$.

Konsentrasi spermatozoa semen segar kambing Kejobong muda dan dewasa berturut-turut adalah $5,17 \pm 1,06 \quad$ x $10^{9}$ spermatozoa $/ \mathrm{ml}$ dan $5,77 \pm 1,21 \times 10^{9}$ spermatozoa/ml (Tabel 3). Tingginya konsentrasi spermatozoa tersebut berhubungan dengan warna dan konsistensi semen. Hasil penelitian ini lebih rendah dari hasil penelitian Hanum et al. (2012) yang melaporkan bahwa konsentrasi spermatozoa semen segar kambing Kejobong muda dan dewasa berturut-turut sebesar $7,94 \pm 2,21 \times 10^{9}$ spermatozoa/ml dan $5,89 \pm 1,49 \times$ $10^{9}$ spermatozoa/ml.

Abnormalitas adalah persentase banyaknya spermatozoa yang morfologinya abnormal dibandingkan dengan spermatozoa yang morfologinya normal. Hasil penelitian menunjukkan abnormalitas spermatozoa kambing Kejobong muda dan dewasa berturut-turut adalah $6,58 \pm 2,87 \%$ dan $6,01 \pm 2,17 \%$. Bearden dan Fuquay (1997) menyatakan bahwa abnormalitas spermatozoa $8-10 \%$ tidak memberi pengaruh yang cukup berarti bagi fertilitas, namun jika abnormalitas lebih dari $25 \%$ dari satu ejakulat maka penurunan fertilitas tidak dapat diantisipasi. Dengan demikian, semen kambing Kejobong muda dan dewasa dapat dikategorikan memiliki morfologi yang baik.

Hasil pengamatan spermatozoa hidup pada kambing Kejobong muda dan dewasa berturut-turut adalah $80,53 \pm 7,69 \%$ dan $82,58 \pm 6,84 \%$. Hasil penelitian ini lebih rendah jika dibandingkan dengan persentase spermatozoa hidup kambing PE. Ariantie et al. (2013) melaporkan bahwa persentase spermatozoa hidup pada kambing PE adalah $84,90 \pm 4,37 \%$.

Kadar testosteron antara kambing Kejobong muda dan dewasa menunjukkan tidak ada perbedaan dengan kadar testosteron berturut-turut

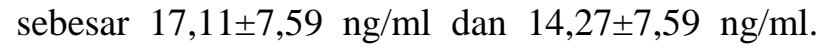
Hasil ini lebih tinggi jika dibandingkan dengan kadar testosteron pada domba Garut dan domba Racka. Hastono dan Arifin (2006) melaporkan bahwa rerata kadar testosteron domba Garut adalah $3,46 \pm 3,2 \mathrm{ng} / \mathrm{ml}$ dengan kadar terendah 0,64-9,55 $\mathrm{ng} / \mathrm{ml}$. Hasil penelitian Sarlos et al. (2013) pada kambing Racka, melaporkan bahwa konsentrasi testosteron plasma darah terendah $(2,31 \pm 0,14 \mathrm{ng} / \mathrm{ml})$ diukur pada musim dingin dan tertinggi pada musim gugur $(17,81 \pm 0,7 \mathrm{ng} / \mathrm{ml})$. Faktor yang mempengaruhi kadar testosteron dalam darah adalah bangsa, tipe kelahiran, dan umur (Langford et al., 1998); musim, lamanya siang dan

Tabel 3. Volume semen, kualitas semen dan kadar testosteron kambing Kejobong muda dan dewasa (semen volume, semen quality and testosterone levels of young and adult Kejobong buck)

\begin{tabular}{|c|c|c|}
\hline \multirow[b]{2}{*}{ Variabel (variable) } & \multicolumn{2}{|c|}{ Kambing Kejobong jantan (Kejobong buck) } \\
\hline & $\begin{array}{l}\text { Muda (young) } \\
(\mathrm{n}=20)\end{array}$ & $\begin{array}{c}\text { Dewasa (adult) } \\
(\mathrm{n}=15)\end{array}$ \\
\hline Volume semen $(\mathrm{ml})$ (semen volume $(\mathrm{ml}))$ & $0,62 \pm 0,24$ & $0,50 \pm 0,21$ \\
\hline Warna (color): & & \\
\hline - Putih susu (\%) (milky-white (\%)) & 10,00 & 6,70 \\
\hline - $\operatorname{Krem}(\%)($ creamy $(\%))$ & 90,00 & 93,30 \\
\hline Konsistensi (consistency): & & \\
\hline - Encer (\%) (liquid (\%)) & 5,00 & 6,70 \\
\hline - Kental (\%) (thick (\%)) & 30,00 & 13,30 \\
\hline - Sangat kental (\%) (thickest (\%)) & 65,00 & 80,00 \\
\hline $\mathrm{pH}$ & $6,41 \pm 0,67$ & $6,48 \pm 0,17$ \\
\hline $\begin{array}{l}\text { Motilitas }(\%)(\text { motility }(\%)) \\
\text { Konsentrasi }\left(\mathrm{x} 10^{9} \text { spermatozoa/ml }\right)(\text { concentration } \\
\left.\left(x 10^{9} \text { spermatozoa/ml }\right)\right)\end{array}$ & $\begin{array}{r}82,00 \pm 8,33 \\
5,17 \pm 1,06\end{array}$ & $\begin{array}{r}85,00 \pm 5,40 \\
5,77 \pm 1,21\end{array}$ \\
\hline Abnormalitas (\%) (abnormality (\%)) & $6,58 \pm 2,87$ & $6,01 \pm 2,17$ \\
\hline Spermatozoa hidup (\%) (live sperm (\%)) & $80,53 \pm 7,60$ & $82,58 \pm 6,84$ \\
\hline Kadar testosteron $(\mathrm{ng} / \mathrm{ml})($ testosterone levels $(\mathrm{ng} / \mathrm{ml}))$ & $17,11 \pm 7,59$ & $14,27 \pm 7,59$ \\
\hline
\end{tabular}


malam (circadian rythms), frekuensi pengambilan, ada tidaknya stimulasi seksual serta sensitivitas dan tingkat ketelitian dari metode yang digunakan (Pineda dan Dooley, 2003).

Hasil penelitian volume semen, $\mathrm{pH}$, motilitas, konsentrasi, abnormalitas, sperma hidup, dan kadar testosteron antara kambing Kejobong muda dan dewasa menunjukkan tidak berbeda nyata. Hal ini menunjukkan bahwa produksi dan kualitas semen kambing Kejobong muda dan dewasa relatif sama. Hasil penelitian ini sejalan dengan penelitian Hanum et al. (2012) yang menyatakan bahwa kualitas semen kambing Kejobong muda dan dewasa tidak berbeda nyata kecuali pada parameter volume semen.

\section{Korelasi lingkar skrotum dengan volume semen, kualitas semen, dan kadar testosteron}

Hasil penelitian (Tabel 4) menunjukkan bahwa korelasi LS dengan volume semen, motilitas, konsentrasi spermatozoa, dan kadar testosteron menunjukkan korelasi yang lemah $(r<0,50)$ dan tidak berbeda nyata, kecuali korelasi LS dengan kadar testosteron pada kambing Kejobong muda menunjukkan adanya korelasi yang sedang $(r=-0,66)$ dan berbeda nyata $(P<0,05)$. Lemahnya hubungan antara LS dengan volume semen dan kualitas semen pada kambing Kejobong muda dan dewasa menunjukkan bahwa pengaruh LS terhadap volume semen dan kualitas semen adalah kecil dan secara statistik tidak ada pengaruhnya.

Hasil penelitian ini sejalan dengan yang dilaporkan oleh Hastono dan Arifin (2006) yang menyatakan bahwa tidak terdapat hubungan antara LS dengan volume semen, konsentrasi spermatozoa pada domba Garut. Hal yang sama juga disampaikan oleh Samsudewa et al. (2012) bahwa korelasi antara ukuran testis dengan volume semen dan konsentrasi spermatozoa menunjukkan korelasi yang lemah hingga sedang dan tidak berbeda nyata pada kambing Kejobong. Hasil yang berbeda dilaporkan oleh Kostaman et al. (2004) yang menyatakan bahwa kambing jantan muda umur \pm 11 bulan, hubungan antara LS dengan volume semen, motilitas dan konsentrasi spermatozoa menunjukkan hubungan yang sangat nyata $(\mathrm{P}<0,01)$ dengan koefisien korelasi (r) berturut-turut 0,98; 0,99 dan 0,91 . Perbedaan hasil penelitian ini dimungkinkan karena perbedaan bangsa kambing.

Tidak adanya pengaruh LS terhadap volume semen karena volume semen dipengaruhi oleh kandungan plasma semen yang disekresikan oleh kelenjar-kelenjar kelamin pelengkap dan epididimis. Keberadaan kelenjar-kelenjar kelamin pelengkap tersebut berada di luar testis, sehingga tidak mempengaruhi ukuran testis. Toelihere (1993) menyatakan bahwa sekitar $90 \%$ volume semen terdiri dari plasma semen.

Lingkar skrotum yang besar diasumsikan memiliki sel sertoli yang lebih banyak sehingga akan meningkatkan motilitas spermatozoa karena banyaknya nutrisi yang disediakan oleh sel sertoli, namun hasil penelitian menunjukkan bahwa ukuran LS tidak berkorelasi dengan motilitas spermatozoa. Garner dan Hafez (2000) menyatakan bahwa motilitas spermatozoa sangat dipengaruhi oleh panas yang berlebihan dan keberadaan benda asing serta bahan-bahan kimia yang dapat mengganggu kelangsungan hidup spermatozoa. Ada dua faktor yang mempengaruhi tingkat motilitas spermatozoa, yaitu faktor endogen (usia, maturasi spermatozoa, ketersediaan energi, dan kemampuan bertahan terhadap benda asing) dan faktor eksogen (lingkungan, stimulasi, dan inhibitor).

Lingkar skrotum yang besar juga diasumsikan memiliki sel leydig yang lebih banyak

Tabel 4. Koefisien korelasi lingkar skrotum dengan volume semen, kualitas semen, dan kadar testosteron kambing Kejobong muda dan dewasa (coefficient correlation of scrotal circumference with semen volume, semen quality and testosterone levels of young and adult Kejobong buck)

\begin{tabular}{lcc}
\hline \hline \multicolumn{1}{c}{ Hubungan/korelasi (correlation) } & \multicolumn{2}{c}{$\begin{array}{c}\text { Koefisien korelasi kambing Kejobong jantan } \\
\text { (coefficient of correlation Kejobong buck) }(\mathrm{r})\end{array}$} \\
\cline { 2 - 3 } & $\begin{array}{c}\text { Muda (young) } \\
(\mathrm{n}=20)\end{array}$ & $\begin{array}{c}\text { Dewasa (adult) } \\
(\mathrm{n}=15)\end{array}$ \\
\hline $\begin{array}{l}\text { Lingkar skrotum-volume semen (scrotal } \\
\text { circumference-semen volume) }\end{array}$ & 0,23 & $-0,01$ \\
$\begin{array}{l}\text { Lingkar skrotum-motilitas (scrotal circumference- } \\
\text { motility) }\end{array}$ & 0,25 & 0,27 \\
$\begin{array}{l}\text { Lingkar skrotum-konsentrasi (scrotal circumference- } \\
\text { concentration) }\end{array}$ & $-0,41$ & $-0,31$ \\
$\begin{array}{l}\text { Lingkar skrotum-kadar testosteron (scrotal } \\
\text { circumference-testesterone levels) }\end{array}$ & $-0,66 *$ & 0,27 \\
$*$ Ada korelasi dan berbeda nyata $(\mathrm{P}<0,05)$ (there was a correlation and significant different $(P<0.05))$.
\end{tabular}


sehingga lebih banyak memproduksi testosteron yang akan meningkatkan pembentukan spermatozoa, namun hasil penelitian menunjukkan bahwa LS tidak berkorelasi dengan konsentrasi spermatozoa. Hal ini dapat dijelaskan karena tingginya kadar testosteron selain meningkatkan produksi spermatozoa juga meningkatkan sekresi cairan plasma semen. Jika sekresi cairan plasma semen meningkat maka volume semen ikut meningkat akibatnya konsentrasi spermatozoa dalam ejakulat menjadi menurun. Toelihere (1993) menyatakan bahwa kelenjar kelamin pelengkap dan epididimis mensekresikan cairan plasma semen karena adanya pengaruh testosteron dari testis. Hal ini terbukti pada jantan yang dikastrasi, unsur-unsur organik spesifik termasuk fruktosa, asam sitrat, sorbitol, inositol, glycerylphosphoryl-choline (GPC), ergothioneine dan prostaglandin, menghilang dari plasma semen dan muncul kembali setelah testosteron disuntikkan kepada ternak jantan tersebut.

Korelasi LS dengan kadar testosteron pada kambing Kejobong muda menunjukkan korelasi yang sedang $(\mathrm{r}=-0,66)$ dan berbeda nyata $(\mathrm{P}<0,05)$ (Tabel 4) dengan persamaan regresi $\mathrm{Y}=14,353$ 0,436X. Ukuran LS pada kambing Kejobong muda berbanding terbalik dengan kadar testosteron. Hal ini dapat dijelaskan karena pada kambing Kejobong muda (umur 8-12 bulan) organ kelamin dan kelenjar kelamin pelengkapnya sedang tahap pertumbuhan. Jika ukuran testisnya masih kecil maka kadar testosteron dalam darahnya tinggi dan sebaliknya. Toelihere (1993) menyatakan bahwa pada kambing jantan umur pubertas (7-12 bulan) hormon-hormon adenohipofisa (FSH dan LH/ICSH) akan merangsang sel leydig dalam testis untuk mensintesis hormon testosteron. Pelepasan hormon testosteron dalam darah menyebabkan pertumbuhan organ reproduksi dan sifat-sifat kelamin sekunder. Samsudewa dan Purbowati (2006) menyatakan bahwa perkembangan organ reproduksi dipengaruhi oleh testosteron seiring bertambahnya umur sampai umur tertentu.

Korelasi LS dengan kadar testosteron pada kambing Kejobong dewasa menunjukkan korelasi yang lemah $(\mathrm{r}=0,27)$ dan tidak berbeda nyata (Tabel 4). Tidak adanya hubungan antara LS dengan kadar testosteron pada kambing Kejobong dewasa menunjukkan bahwa kadar testosteron tidak dipengaruhi oleh ukuran LS. Hal ini karena pada kambing Kejobong dewasa pertumbuhan testis dan kelenjar kelamin pelengkap lainnya sudah hampir sempurna, sehingga pertambahan ukuran LS-nya sangat lambat. Testosteron yang dihasilkan oleh kambing dewasa sebagian besar digunakan dalam proses spermatogenesis.

\section{Kesimpulan}

Lingkar skrotum kambing Kejobong muda berkorelasi positif dengan bobot badan dan berkorelasi negatif dengan kadar testosteron sedangkan dengan volume dan kualitas semen tidak berkorelasi. Lingkar skrotum kambing Kejobong dewasa tidak berkorelasi dengan bobot badan, volume semen, kualitas semen, dan kadar testosteron.

\section{Ucapan Terima Kasih}

Penulis mengucapkan terima kasih kepada Balitbangda Provinsi Jawa Tengah dan Laboratorium Genetika, Pemuliaan dan Reproduksi, Fakultas Peternakan dan Pertanian UNDIP atas pendanaan penelitian; Laboratorium Fisologi, Fakultas Kedokteran Hewan, UGM; Dinas Peternakan dan Perikanan Kab. Purbalingga; Penyuluh Peternakan, Ketua dan anggota Kelompok Tani Ternak (KTT) di kecamatan Kejobong, Pengadegan dan Bukateja; Kepala Desa Pangempon, Ibu Suparmi, atas akomodasi dan fasilitasnya.

\section{Daftar Pustaka}

Ariantie, O. S., T. L., Yusuf, D. Sajuthi, dan R. I. Arifiantini. 2013. Pengaruh krioprotektan gliserol dan dimethilformamida dalam pembekuan semen kambing Peranakan Etawah menggunakan pengencer tris modifikasi. Jurnal Ilmu Ternak dan Veteriner 18: 239-250.

Ax, R. L., M. R. Dally, B. A. Didion, R. W. Lenz, C. C. Love, D. D. Varner, B. Hafez and M. E. Bellin. 2000. Semen evaluation. In: Reproduction in Farm Animals. $7^{\text {th }}$ ed. B. Hafez and E. S. E. Hafez (eds). Lippincott Williams \& Wilkins, Philadelphia. Pp: 365375.

Bearden, H. J. and J. W. Fuquay. 1997. Applied Animal Reproduction. $4^{\text {th }}$ ed. Prentice Hall. Upper Saddle. New Jersey.

Garner, D. L. and E. S. E. Hafez. 2000. Spermatozoa and seminal plasma. In: Reproduction in Farm Animals. $7^{\text {th }}$ ed. B. Hafez and E. S. E. Hafez (eds). Lippincott Williams \& Wilkins, Philadelphia. Pp: 96109. 
Hanum, A. N., E. T. Setiatin, D. Samsudewa, E. Kurnianto, E. Purbowati, dan Sutopo. 2012. Perbandingan kualitas semen kambing Kejobong dan kambing Kacang di Jawa Tengah. Prosiding Seminar Nasional Peternakan Berkelanjutan ke-4. Fakultas Peternakan, Universitas Padjajaran. Bandung.

Hastono dan J. Arifin. 2006. Pengaruh lingkar skrotum terhadap kandungan testosteron, volume semen dan konsentrasi sperma domba Garut. Prosiding Seminar Nasional Teknologi Peternakan dan Veteriner. Pusat Penelitian dan Pengembangan Peternakan. Bogor.

Hastono, I. Inounu, dan N. Hidayati. 2001. Karakteristik semen dan tingkat libido domba persilangan. Prosiding Seminar Nasional Teknologi Peternakan dan Veteriner. Pusat Penelitian dan Pengembangan Peternakan. Bogor.

Ismaya. 1993. Hubungan antara besar skrotum dengan volume semen, motilitas dan konsentrasi spermatozoa pada domba lokal. Buletin Peternakan 17: 34-37.

Judge, M. D., E. D. Aberle, J. C. Forrest, H. B. Hedrick and R. A. Merkel. 1989. Principles of Meat Science. Kendall/Hunt Publishing Co. Iowa.

Kaya, A., M. Aksoy and T. Tekeli. 2002. Influence of ejaculation frequency on sperm characteristics, ionic composition and enzymatic activity of seminal plasma in rams. J. Small Rum. Res. 44: 153-158.

Knight, S. A., R. L. Baker, D. Gianola and J. B. Gibb. 1984. Estimates of heritabilities and of genetics and phenotypic correlations among growth and reproductive traits in yearling Angus bulls. J. Anim. Sci. 58: 887-893.

Kostaman, T., M. Martawidjaja, I. Herdiawan, dan I. K. Sutama. 2004. Hubungan antara lingkar skrotum dengan bobot badan, volume semen, motilitas progresif dan konsentrasi spermatozoa pada kambing jantan muda. Prosiding Seminar Nasional Teknologi Peternakan dan Veteriner. Pusat Penelitian dan Pengembangan Peternakan. Bogor.

Koyuncu, M., S. K. Uzun and S. Duru. 2005. Development of testicular dimensions and size, and their relationship to age and body weight in growing Kivircik (western thrace) ram lambs. Czech. J. Anim. Sci. 50: 243-248.

Langford, G. A., J. N. B. Sheretha, L. M. Sanford and G. J. Marcus. 1998. Reproductive hormone levels of early postpubertal ram lambs in relation to breed, adult testis size and semen quality. J. Small Rum. Res. 29: 225-231.
Pineda, M. H. and M. P. Dooley. 2003. Veterinary Endocrinology and Reproduction. $5^{\text {th }}$ ed. Blackwell Publishing. Iowa.

Pramono, D., Muryanto, Subiharta, D. Asih, D. W. Purwanti, S. W. Nugroho, H. Santoso, Suyono, T. Prasetyo, C. Setiani, dan D. W. Yuwono. 2005. Sumberdaya hayati ternak lokal Jawa Tengah. Laporan Kerjasama Dinas Peternakan Provinsi Jawa Tengah dengan Balai Pengkajian Teknologi Pertanian Jawa Tengah. Semarang. (Tidak dipublikasikan).

Samsudewa, D. dan E. Purbowati. 2006. Ukuran organ reproduksi domba lokal jantan pada umur yang berbeda. Prosiding Seminar Nasional Teknologi Peternakan dan Veteriner. Pusat Penelitian dan Pengembangan Peternakan. Bogor.

Samsudewa, D., E. Kurnianto, E. T. Setiatin, Sutopo, E. Purbowati, A. N. Hanum, S. B. Wibowo, dan K. A. Permana. 2012. Hubungan ukuran organ reproduksi dan kualitas semen kambing Kacang dan kambing Kejobong. Prosiding Seminar Nasional Peternakan Berkelanjutan ke-4. Fakultas Peternakan, Universitas Padjajaran. Bandung. Sarlos, P., I. Egerszegi, O. Balogh, A. Molnar, S. Cseh and J. Ratky. 2013. Seasonal changes of scrotal circumference, blood plasma testosterone concentration and semen characteristics in Racka rams. J. Small Rum. Res. 111: 90-95.

Sodiq, A. 2009. Karakterisasi sumberdaya kambing lokal khas Kejobong di Kabupaten Purbalingga Provinsi Jawa Tengah. J. Agrivet. 9: 31-37.

Soeparno. 2005. Ilmu dan Teknologi Daging. Edisi ke-4. Gadjah Mada Press. Yogyakarta.

Steel, R. G. D. and J. H. Torrie. 1993. Prinsip dan Prosedur Statistika. (Diterjemahkan oleh B. Sumantri). PT. Gramedia. Jakarta.

Sumardianto, T. A. P., E. Purbowati, dan Masykuri. 2013. Karakteristik karkas kambing Kacang, kambing Peranakan Ettawa dan kambing Kejobong jantan pada umur satu tahun. J. Anim. Agri. 2: 175-182.

Toelihere, M. R. 1993. Fisiologi Reproduksi pada Ternak. Angkasa. Bandung.

Wahid, A. S. and J. M. Yunus and M. Ariffiri. 1991. Seasonality in libido and semen production in temperate rams. Proceeding Livestok and Feed Development in the Tropics. Malang.

Wahid, A. S. and J. M. Yunus. 1994. Correlation betweeen testicle measurement and libido and semen quality in ram. Asian-Aust. J. Anim. Sci. 7: 175-178. 
Wahid, A. S. and J. M. Yunus. 1995. Level of testosterone in blood plasma of selected rams. Asian-Aust. J. Anim. Sci. 8: 582-585. 